\title{
Adverbial Clauses in English and Norwegian Fiction and News
}

\author{
Hilde Hasselgård, University of Oslo
}

\begin{abstract}
This paper considers the placement of adverbial clauses in English and Norwegian with regard to their form, meaning, information status and semantic relation to the matrix clause proposition. The study is based on comparable original texts in both languages, representing two registers: fiction and news reportage. End position of adverbial clauses is most common in both languages, with initial position as an alternative in many cases. Positional freedom is found to differ greatly between finite and non-finite clauses, and also across different semantic types of adverbial clauses. For those types of adverbial clauses that vary across positions, mostly time and contingency clauses, information status (new vs. anchored) is found to have some influence. Iconic order was found to be less important, but was more noticeable in fiction than in news. The placement of adverbial clauses seems to be guided by similar principles in both languages. Register differences are identified in both languages, but they do not show consistent patterns.
\end{abstract}

Keywords: adverbial clauses, information structure, iconic word order, adverbial placement, register, English, Norwegian

\section{$1 \quad$ Introduction}

This study presents a comparison of adverbial clause placement in English and Norwegian with regard to form, meaning, information structure, text strategy and register. The syntax of both languages allows an adverbial clause to occur before or after the matrix clause, and more marginally, clause-medially within the matrix. However, similar syntactic possibilities do not automatically entail similar patterns of use: the languages may exploit the possibilities in different ways due to differences in their preferred syntactic and discourse-organizational patterns. One aim is therefore to find out whether the principles governing the placement of adverbial clauses differ between English and Norwegian. Previous cross-linguistic studies of adverbial clauses have found that their placement varies across languages, see e.g. Diessel (2001) and Hetterle (2015), but neither of these studies includes Norwegian. Secondly, since grammar has been shown to vary across registers (e.g. Biber et al. 1999; Diessel 2005), another research question is whether the placement of adverbial clauses is different between registers. The study is primarily based on comparable corpora of original fiction and news texts in English and Norwegian; see sect. 3. The analysis involves a number of factors believed to have an impact on adverbial clause placement, both within and across registers and languages. These include the form and meaning of the adverbial clause; e.g. whether it is finite or non-finite and whether it denotes time, contingency, manner, etc. At the level of discourse, the investigation concerns the extent to which the placement of adverbial clauses is affected by information structure and finally whether the ordering of the adverbial clause and

Hilde Hasselgård

University of Oslo, Norway

e-mail: hilde.hasselgard@ilos.uio.no 
the matrix can be said to reflect the text-strategic principle of experiential iconicism (e.g. Enkvist 1981).

The article is structured as follows: after an overview of basic definitions (sect. 2), relevant previous research on the topic (sect. 3) and the material and method of the study (sect. 4), the main analysis is presented in sect. 5-7. Section 5 is concerned with lexicogrammatical features of adverbial clauses and adverbial placement at sentence level. Particular attention is given to placement in relation to the syntactic realization of adverbial clauses (sect. 5.2) and the semantic type of adverbial clause (sect. 5.3). Section 6 discusses adverbial clause placement in relation to information structure, section 7 looks into the role of experiential iconicism in the ordering of clauses, and section 8 offers a summary of findings and some concluding remarks.

\section{Some Basic Definitions}

Adverbial clauses are defined by Hetterle (2015: 2) as "clausal entities that modify, in a very general sense, a verb phrase or a main clause and explicitly expresses a conceptual-semantic concept such as SIMULTANEITY, ANTERIORITY, POSTERIORITY, CAUSALITY Or CONDITIONALITY". In more traditional terms they are subordinate clauses, finite and non-finite, which have the function of (adjunct) adverbial in a matrix clause (e.g. Biber et al. 1999: 194). Finite adverbial clauses in both English and Norwegian are typically marked by "a subordinator indicating the relationship to the main clause" (ibid.; see also Faarlund et al. 1997: 800). English non-finite adverbial clauses include infinitive clauses, participle clauses (-ing and -ed) and verbless clauses, as well as a category of 'prepositional clauses', i.e. a clause governed by a preposition. ${ }^{1}$ Norwegian non-finite clauses in the present material are invariably prepositional clauses, typically an infinitive governed by a preposition as in (1). English prepositional clauses typically contain -ing participles, as shown in the idiomatic translation in (1). Norwegian prepositional clauses, unlike English ones, can also be finite as illustrated in (2); ${ }^{2}$ hence they are divided into prepositional non-finites and prepositional finites.

(1) Vi satt uten å si noe. (LSC2)

Lit: "We sat without to say anything".

We sat there without saying anything. (LSC2T)

(2) Til tross for at han hadde drukket konjakk, ønsket han å være usynlig. (OEL1)

Lit: "In spite of that he had drunk cognac, wished he to be invisible"

In spite of the cognac he wanted to be invisible. (OEL1T)

The adverbial clauses are furthermore classified semantically into the following categories: time, space, manner, contingency, respect, and comparison; see Hasselgård (2010: 39).

\footnotetext{
${ }^{1}$ The reason for regarding such constructions as clauses rather than phrases is that they invariably contain a proposition and are also clause-like in their positional preferences; see Hasselgård (2010: 37).

${ }^{2}$ Examples (1) and (2) come from the English-Norwegian Parallel Corpus (ENPC). In ENPC examples the original is given first. Norwegian examples are followed by a word-for-word translation, while the published (idiomatic) translation is followed by a tag ending in $-\mathrm{T}$.
} 
Contingency clauses comprise adjuncts of condition, concession, cause and purpose (ibid.); see examples (6)-(11) in sect. 5.3.

Adverbial positions are classified as in Biber et al. (1999: 771) and Hasselgård (2010: $41 \mathrm{ff}$ ), into initial, medial and end position. Initial is the position before the matrix clause, as in (2) and (3); medial position is after the subject, but before any postverbal obligatory element of the matrix clause, as in (4); and end position is after the matrix clause, as in (1) and (5). The same positions are identified for both languages. For definitions concerning information structure and text strategy, see sect. 6 and 7.

(3) Unless something's done about her she'll end up like her mother. (ICE-GB: W2F)

(4) A 19th-century ornithologist, Robert Gray, when visiting the island in the 1860s, described an occasion on Ailsa Craig when he disturbed the puffin population. (ICE-GB: W2C)

Josh nodded before straightening up away from the gate. (ICE-GB: W2F)

\section{Previous Work on Adverbial Clauses in English and Norwegian}

A number of studies, including reference grammars, describe aspects of adverbial clause placement in English. The literature on Norwegian is more scant, as are contrastive studies of English and Norwegian. This section gives a brief overview of some relevant studies.

Biber et al. (1999: $830 \mathrm{ff}$ ) observe that English adverbial clauses are common in both initial and end position, while medial position is a highly marked choice. End position is identified as the unmarked position for all types of non-finite adverbial clauses (ibid.: 831). Most types of finite adverbial clauses also prefer end position, but display more variation than non-finite clauses, depending on semantic type. The factors believed to influence the placement of adverbial clauses are cohesion, information structuring, discourse framing, and structural considerations (i.e. "the length of the adverbial clause and whether or not it is located within another dependent clause", p. 837). Initial finite clauses are said to frequently contain given information and precede a matrix clause containing new information (p. 835). Adverbial clauses with new information, on the other hand, "tend to be in final position" (ibid.).

The order of constituents - including clausal ones - in a sentence may be influenced by what Enkvist (1981) refers to as "experiential iconicism", a text strategy whose purpose is "to make the text mimetic of experience" (1981: 101). In other words, the order of clauses, according to the principle of experiential iconicism, can mimic the order of events in the world, and is therefore also referred to as "natural order".

Altenberg (1987), in a study of causal ordering strategies, finds that causal clauses are rare in initial position, particularly in conversation. Instead the cause-effect (or cause-result) order is typically realised by a main clause where causality is left implicit and a following 
clause starting with so (1987: 56). Thus, "natural ordering rarely affects because-clauses" (ibid.: 58).

Ford (1993) studies temporal and conditional clauses in conversation. She argues that conditional clauses are frequent in initial position due to their discourse-organizational work. She points out that adverbial clauses in initial and end position have different textual functions. Temporal clauses in initial position signal backgrounded information. On the other hand, "final adverbial clauses specify main clause meaning, but do not participate in information patterning strategies as do initial adverbials" (1993: 134).

Diessel (2005) studies conditional, temporal and causal clauses in three registers of English: conversation, fiction and science. He finds the semantic types of clauses to have different positional tendencies, with conditionals being initial in the majority of cases (67$73 \%$ ), while the other two are sentence-final in the majority of cases (34-41\% of temporal clauses are initial, and 1-27\% of causal clauses). The registers also differ markedly, especially with regard to the position of causal clauses, which are most frequent in clause-initial position in science texts and least in conversation (see Diessel 2005: 454). Diessel argues that the placement of adverbial clauses is governed by three competing forces: processing (which favours final placement (ibid.: 459)), semantics (acknowledging that "different semantic types of adverbial clauses differ in their distribution", (ibid.: 465)), and discourse-pragmatic factors, including information structure and iconicity, which can often explain the choice of initial position (ibid.). In a follow-up study, Diessel (2008) looks specifically at how the placement of temporal clauses introduced by when, after, before, once, and until may be determined by "iconicity of sequence" (passim). Iconicity is found to have a "strong and consistent effect on the linear structuring of complex sentences with temporal adverbial clauses" (2008: 483), but this factor is more clearly visible with initial than with final adverbial clauses. The placement of an adverbial clause is also found to be influenced by its length relative to the main clause as well as by the conjunction introducing it (ibid.: 484).

Thompson et al. (2007: $271 \mathrm{ff}$ ) discuss initial adverbial clauses as a means of cohesion both within and across paragraphs. In both cases an initial adverbial clause is cohesive by means of back-reference to the previous sentence or paragraph. However, initial adverbial clauses are also said to be "bidirectional, linking what has gone before to what is to come" (2007: 296). Conversely, the information encoded in a postposed adverbial clause "may be significant, closely parallel to that encoded in clauses in coordination", and an adverbial clause in end position may even "convey globally crucial information and mark a turning point or peak" (ibid.).

Hasselgård (2010) studies adjunct adverbials in general, and makes particular note of adjuncts realized by clauses. $74 \%$ of adverbial clauses are found in end position, $24 \%$ in initial position, and $2 \%$ in medial position (2010: 87). The semantic type to occur most frequently in initial position is contingency (ibid.), followed at a distance by time. However, the same two categories are also the most common ones in end position (ibid.: 136), reflecting that time and contingency are the most common meanings conveyed by adverbial clauses overall. It is suggested that

adverbial clauses are placed initially if they do one or more of the following discourse jobs: (i) provide a setting / frame of reference for the following clause(s); (ii) provide a relevant and/or 
necessary restriction on the validity of the matrix clause proposition; (iii) provide a link to the preceding discourse by means of given information or cohesive devices (2010: 91).

Wichmann \& Kertz (2013) study the placement of concessive clauses in English in relation to formal and discourse-pragmatic variables as well as processing factors. They conclude that "the two strongest predictors in our study, are semantic or discourse organizational in nature" (2013: 19); in particular, an adverbial clause is likely to be fronted if it contains an anaphoric item (ibid.: 20). Processing factors, though significant, are found to play only a subsidiary role when weighed against other variables.

No studies have been found that explicitly contrast initial and end position of adverbial clauses in Norwegian. However, the Norwegian reference grammar (Faarlund et al. 1997) remarks on the typical positions of some adverbial clause types, identified by the conjunction used to introduce them. Causal clauses introduced by fordi ('because') are said to occur in initial position if they convey presupposed information and in end position if they convey new information (1997: 1036). Purpose clauses introduced by slik at ('so that') are typically in end position while those introduced by for at ('for that') can vary between the positions (ibid.: $1040 \mathrm{f}$ ). No positional tendency is noted for conditional clauses in general, but it is claimed that conditionals marked by inversion rather than a subjunction are always initial (ibid.: 1046).

Fossestøl (1980: $280 \mathrm{ff}$ ) discusses the relationship between the temporal sequence of events and the linear sequence of clauses, noting that adverbial clauses with fordi ('because') tend to be sentence final, thus reversing the temporal sequence of the cause and consequence. However, he does not offer a detailed study of adverbial clause placement, but simply puts forward some principles of text organization.

Meier (2001) is a contrastive study of causal subordination in English and Norwegian based on the English-Norwegian Parallel Corpus (ENPC). Meier found that clauses introduced by because and its closest Norwegian counterpart fordi are typically found in end position while clauses introduced by other causal subordinators (English as, since and Norwegian siden, ettersom) are more likely to occur in initial position. This is linked to the information typically conveyed by such clauses as well as the range of pragmatic functions typically served.

Hasselgård (2014a) investigates the discourse functions of initial adjunct adverbials in English and Norwegian, based on the same material as the present study (see sect. 4). Initial adjuncts are found to be more frequent in Norwegian than in English, partly as a consequence of a generally higher frequency of adjuncts. Initial placement of adjuncts seems to be less marked in Norwegian, and initial adjuncts are commonly used for discourse linking.

Hasselgård (2014b) studies conditional clauses in English and Norwegian on the basis of the non-fiction part of the ENPC. Conditionals are most frequently found in initial position in both languages, but in original texts, end position is more common in Norwegian than in English. This is linked to the division of conditionals into open, hypothetical and pragmatic (p. 192 f.): in particular, open conditionals are more frequently sentence-final in Norwegian than in English. The similarity between the languages is, however, extensive enough for the position of the conditional clause to be changed very rarely in translation between the languages (p. 198). 
Diessel (2001: $433 \mathrm{f}$ ), in a typologically oriented study, argues that the placement of adverbial clauses in languages that use both initial and final position varies with the meaning and function of the clauses, and to some extent with the choice of subordinator. Hetterle (2015: 121-127) makes similar observations on the positions of adverbial clauses in a number of languages (not including Norwegian or other Scandinavian languages).

As will have been noted, all the studies point to variation in adverbial clause placement according to the semantic type of adverbial clause, information structure, and discourse coherence. While English adverbial clauses have been extensively studied and fairly well described, the contribution of the present study will be the language comparison and the results for Norwegian.

Based on the previous studies, the following findings can be expected for the present one:

- Initial placement of adverbial clauses will be more frequent in Norwegian than in English, partly as a consequence of an overall higher frequency of adverbial clauses, and partly because of different positional preferences between the languages (Hasselgård 2014a \& b).

- News will use initial position more often than fiction (Hasselgård 2014a).

- Different syntactic types of clauses will have different positional preferences (Diessel 2005, Hasselgård 2010). In particular, non-finite clauses will have less freedom of position. The preferences may vary between languages and registers.

- Different semantic types of clauses will have different positional preferences (Diessel 2005 and 2008, Hasselgård 2010). For example, conditional and causal clauses will prefer initial and end position, respectively (Hasselgård 2014b, Altenberg 1987). The preferences may vary between languages and registers.

- Adverbial clauses containing given information are more likely to be sentence-initial; those containing new information are more likely to be sentence-final (Ford 1993, Diessel 2005, Hasselgård 2010).

- Experiential iconicism / iconic order (Enkvist 1981; Diessel 2008) is likely to influence the order of subordinate and matrix clause with the possible exception of causal clauses introduced by becauselfordi; cf. Fossestøl (1980) Altenberg (1987), and Meier (2001).

\section{$4 \quad$ Material and Method for the Current Study}

The English material has been culled from the British component of the International Corpus of English (ICE-GB), and is a subset of the material used for the study of adjunct adverbials in Hasselgård (2010). The Norwegian fiction texts come from the English-Norwegian Parallel Corpus (ENPC), while the Norwegian news texts are a collection of news articles sampled from various online newspapers in March 2011; see Table 1 and the list provided in the references section for details. The adverbial clauses were extracted and analysed manually. A subset was used for the case studies of information structure and experiential iconicism (sect. 6 and 7). Table 1 also shows the frequency of adverbial clauses per 10,000 words, which gives an indication that in English such clauses are more frequent in fiction, whereas in Norwegian they are more frequent in news. 
Table 1 Corpus composition

\begin{tabular}{|l|l|c|c|c|}
\hline Corpus & Source & Words & $\begin{array}{l}\text { N of adverbial } \\
\text { clauses }\end{array}$ & $\begin{array}{l}\text { Adv clauses } \\
\text { per10,000 words }\end{array}$ \\
\hline English fiction & ICE-GB & 10,000 & 146 & 146 \\
\hline English news & ICE-GB & 10,000 & 118 & 118 \\
\hline Norwegian fiction & ENPC & 24,800 & 229 & 92.3 \\
\hline Norwegian news & Online newspapers & 11,000 & 156 & 141.8 \\
\hline
\end{tabular}

However, as occurrence per number of words is not an ideal measure for the frequency of adverbial clauses, the number of adverbial clauses per 100 orthographic sentences was also calculated. The number of sentences in the Norwegian material was calculated with WordSmith Tools (Scott 2014), while for the ICE-GB texts the number of 'text units' given for each corpus text was used. The mean sentence length is practically identical between English and Norwegian, but the registers differ in both languages, with sentences being almost twice as long in news as in fiction (see Fig. 1). This indicates that sentence complexity is greater in news, which correlates with a markedly higher frequency of adverbial clauses per 100 sentences in news than in fiction, as shown by Fig. 1. Frequencies per 100 sentences highlight similarities between the languages and differences between the registers, and thus gives a different picture than the calculation per 10,000 words reported in Table 1: in terms of frequency per sentence Norwegian fiction has fewer adverbial clauses than English fiction, while Norwegian news has more than English news. It should be noted, however, that the opportunity of occurrence for adverbials is not the sentence, but the clause; thus frequency per sentence is not an ideal measure either. The quantitative findings of this study will therefore mainly be given in terms of raw frequencies or proportional distribution of adverbial clauses across positions within each subcorpus.

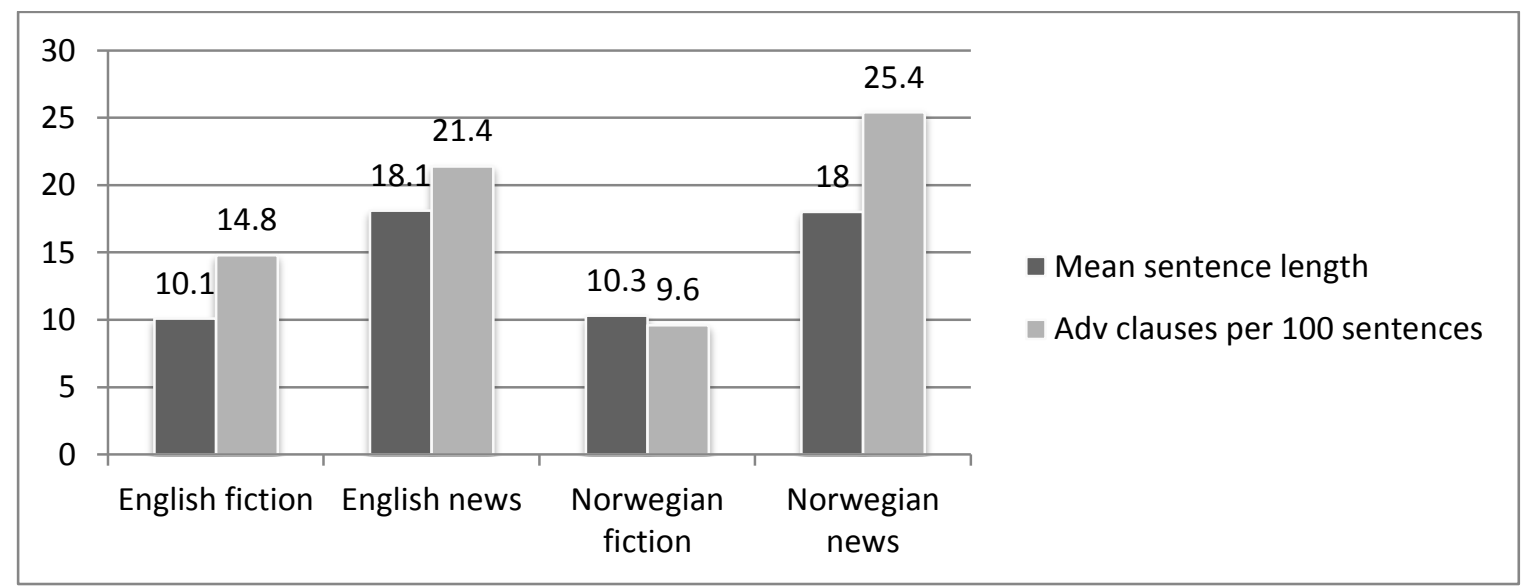

Fig. 1 Mean sentence length and frequency of adverbial clauses per 100 sentences across languages and registers

\section{Positions, Forms and Meanings of Adverbial Clauses}




\subsection{The Placement of Adverbial Clauses}

The hypothesis that Norwegian will use initial position more often than English is at best only partially confirmed, as shown in Table 2: initial position is proportionally more frequent in Norwegian fiction than in English fiction, but for news, the opposite is the case. However, Fisher's exact test shows that the cross-linguistic difference is not statistically significant for either register. ${ }^{3}$ Table 2 may indicate that the hypothesis of a (proportionally) more frequent use of initial position in news than in fiction is correct for English, but not for Norwegian, though the apparently different distribution of initial vs. end position between fiction and news is found to be not statistically significant in both languages.

Table 2 Frequency of positions of adverbial clauses in English and Norwegian fiction and news

\begin{tabular}{|l|c|c|c|c|l|c|c|c|}
\hline & \multicolumn{2}{|c|}{ E fiction } & \multicolumn{2}{c|}{ E news } & \multicolumn{2}{c|}{$\mathrm{N}$ fiction } & \multicolumn{2}{c|}{ N news } \\
\hline & $\mathrm{N}$ & $\%$ & $\mathrm{~N}$ & $\%$ & $\mathrm{~N}$ & $\%$ & $\mathrm{~N}$ & $\%$ \\
\hline Initial & 27 & 18.5 & 27 & 22.9 & 57 & 24.8 & 33 & 21.2 \\
\hline Medial & 1 & 0.7 & 2 & 1.7 & 2 & 0.9 & 0 & 0 \\
\hline End & 118 & 80.8 & 89 & 75.4 & 171 & 74.3 & 123 & 78.9 \\
\hline Total & 146 & 100 & 118 & 100 & 230 & 100 & 156 & 100 \\
\hline E/I ratio & \multicolumn{1}{|c|}{5.4} & \multicolumn{9}{|c|}{4.4} & \multicolumn{2}{c|}{4.0} & \multicolumn{2}{c|}{3.7} \\
\hline
\end{tabular}

Fig. 2 gives a different perspective on the frequencies, which alters the picture to some degree. The figure shows the percentage of sentences in each subcorpus (cf. Fig. 1) that contain an adverbial clause in initial and end position, respectively. From this perspective, initial adverbial clauses are more frequent in news in both languages, but so, it must be noted, are adverbial clauses in end position. For the present, I will not pursue the calculations per sentence any further.

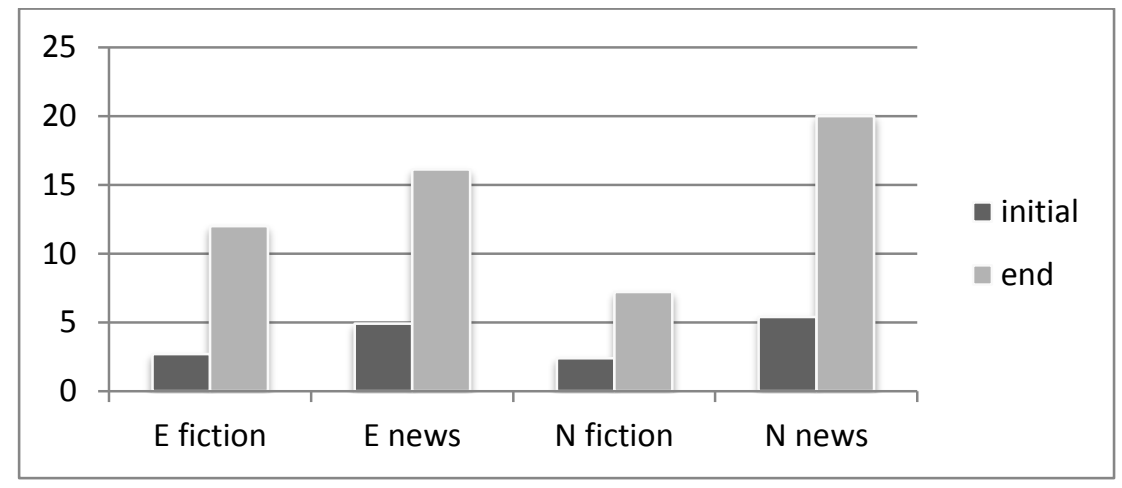

Fig. 2 The percentage of sentences in each subcorpus that contain an initial or final adverbial clause

The findings presented here are inconclusive with regard to the hypotheses presented above. There is a higher frequency of initial adverbial clauses in news than in fiction in both languages, but as this is matched by a higher frequency of final clauses, the percentage of

\footnotetext{
${ }^{3}$ The calculation took only initial and end position into account.
} 
clauses in initial position is greater in news than in fiction only in English. Contrary to expectation, Table 1 and Figures 1 and 2 show adverbial clauses to be less frequent in Norwegian than in English fiction. However, none of the frequency differences observed between languages and registers have proved to be statistically significant.

\subsection{Placement and Syntactic Realization of Adverbial Clauses}

It was predicted that non-finite clauses would have less positional freedom than finite ones, and findings support this hypothesis. Fig. 3 shows the percentage of initial position for finite and non-finite clauses across languages and registers. Non-finite clauses are consistently less frequent in initial position than finite ones across languages and registers. The register difference is greater in Norwegian than in English as regards non-finite clauses, but it is smaller for finite clauses.

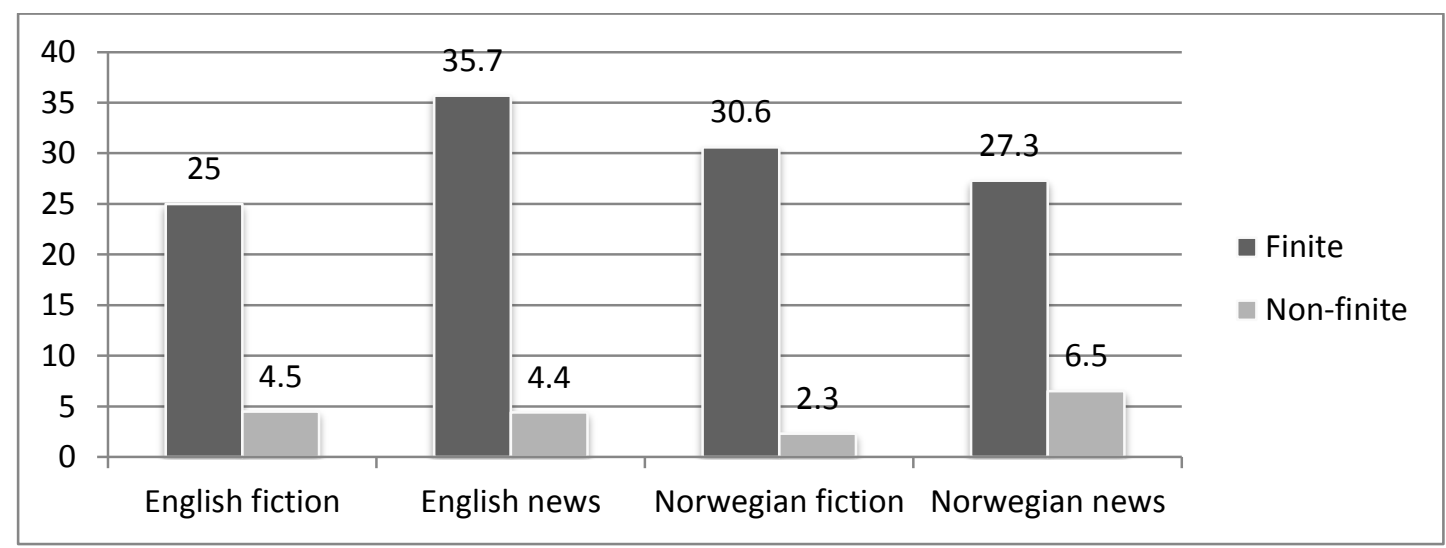

Fig. 3 The percentage of clauses occurring in initial position (in contrast to end position)

The raw frequencies underlying Fig. 3 are shown in Table 3. The differences between finite and non-finite clause placement are consistent across the material and across different types of non-finite clauses. That is, the overwhelming preference of non-finite clauses in both languages and both registers is for end position. The differences in distribution between initial and end position are statistically significant across the material, at $\mathrm{p}<0.01$ for English fiction and Norwegian news and $\mathrm{p}<0.0001$ for English news and Norwegian fiction. Interestingly, prepositional finites show the same tendency as non-finites: only one out of 14 such clauses in the Norwegian material was found in initial position.

Table 3 Positions of finite and non-finite adverbial clauses (raw frequencies)

\begin{tabular}{|l|c|c|c|c|c|c|c|c|}
\hline & \multicolumn{2}{|c|}{ English fiction } & \multicolumn{2}{c|}{ English news } & \multicolumn{2}{c|}{ Norwegian fiction } & \multicolumn{2}{c|}{ Norwegian news } \\
\hline & Initial & End & Initial & End & Initial & End & Initial & End \\
\hline Finite clause & 25 & 75 & 25 & 45 & 55 & 121 & 30 & 73 \\
\hline Prepositional finite & 0 & 0 & 0 & 0 & 1 & 6 & 0 & 7 \\
\hline Non-finite clause & 1 & 35 & 2 & 31 & 0 & 0 & 0 & 3 \\
\hline Prepositional non-finite & 1 & 7 & 0 & 11 & 1 & 43 & 3 & 40 \\
\hline Verbless clause & 0 & 0 & 0 & 1 & 0 & 0 & 0 & 0 \\
\hline & 27 & 117 & 27 & 88 & 57 & 170 & 33 & 123 \\
\hline
\end{tabular}




\subsection{Placement and Semantic Type of Adverbial Clause}

Different semantic types of adverbial clauses have different positional preferences although end position is the most common alternative for all of them, at least in English (e.g. Hasselgård 2010). The same is expected to be the case in Norwegian. Medial position is so rare in the material that its use is practically negligible (cf. Table 2); the remainder of this paper will concentrate on initial and end position.

The following semantic types of adverbial clauses are found in initial position: time, space, manner, contingency, and comparison. In end position the same types are found, along with respect. These are illustrated in examples (6)-(11).

(6) TIME: When he loses his temper with her she runs off (ICE-GB: W2F)

(7) SPACE: but he was better off where he was, keeping a low profile. (ICE-GB: W2F)

(8) MANNER: Hun så på klokken som om han skulle begynne med det samme. (OEL1)

Lit: "She looked at the watch as if he should begin at once"

She looked at her watch as though he was going to begin right away. (OEL1T)

(9) CONTINGENCY (reason, purpose, condition, concession): Dersom andre teknologier holder mål, kan det bli vanskelig for regjeringen å ikke gå inn med statlig støtte. (News: DAV3)

Lit: "If other technologies are up to standard, it can be difficult for the government to not go in with governmental support."

(10) COMPARISON: He went on to say that rather than conducting a war of attrition, BS should release Ravenscraig for sale. (ICE-GB: W2C)

(11) RESPECT: Han sier han ble kontaktet og advarte Andhøy mot å seile $i$ området ... (News: VG2)

Lit: "He says he was contacted and warned Andhøy against to sail in the area..."

Table 4 shows the positional distribution of adverbial clauses according to semantic subtype. Since the subcorpora differ in size and in the number of adverbial clauses they contain, the positional distribution has been calculated proportionally, as a percentage of the total number of clauses in each subcorpus. Time clauses occupy initial position relatively frequently across the material, particularly in fiction; in fact their proportion in Norwegian fiction is the highest in the material. In news, contingency clauses are the most frequent type found in initial position in both languages.

Table 4 The positional distribution of semantic subtypes of adverbial clauses across languages and registers (percentages)

\footnotetext{
${ }^{4}$ Examples from the Norwegian newspaper material are accompanied by a translation (produced by the author) intended to show the structure of the original without being entirely literal.
} 


\begin{tabular}{|l|c|c|c|c|c|c|c|c|}
\hline & \multicolumn{2}{|c|}{$\begin{array}{c}\text { English fiction } \\
\mathrm{N}=145\end{array}$} & \multicolumn{2}{c|}{$\begin{array}{c}\text { English news } \\
\mathrm{N}=116\end{array}$} & \multicolumn{2}{c|}{$\begin{array}{c}\text { Norwegian fiction } \\
\mathrm{N}=227\end{array}$} & \multicolumn{2}{c|}{$\begin{array}{c}\text { Norwegian news } \\
\mathrm{N}=153\end{array}$} \\
\hline & Initial & End & Initial & End & Initial & End & Initial & End \\
\hline Time & 9.7 & 38.6 & 6.9 & 30.2 & 17.2 & 37.4 & 6.5 & 21.3 \\
\hline Space & 0.7 & 1.4 & 0.9 & 0.9 & 0 & 0.4 & 0 & 0.6 \\
\hline Manner & 0 & 4.8 & 0 & 5.2 & 0.4 & 11.5 & 0.6 & 7.7 \\
\hline Contingency & 8.3 & 35.2 & 15.5 & 39.7 & 7.0 & 21.6 & 14.4 & 35.5 \\
\hline Respect & 0 & 0 & 0 & 0.9 & 0 & 2.6 & 0 & 11.0 \\
\hline Comparison & 0 & 1.4 & 0 & 0 & 0.4 & 1.3 & 0 & 2.6 \\
\hline & 18.7 & 81.4 & 23.3 & 76.9 & 25 & 74.8 & 21.5 & 78.7 \\
\hline
\end{tabular}

Most semantic types of adverbial clauses are rare or non-existent outside end position in the present material. It is only with time and contingency clauses that there seems to be a real choice between the positions - at least they are the only categories that are frequent enough in both positions to allow a real comparison. The focus of the next two sections will thus be on these two.

\section{Adverbial Clause Placement and Information Structure}

Studies of information structure typically distinguish between new information (where a referent is not known to the reader/hearer) and given (old/known) information. In spite of this apparently simple dichotomy, information status is notoriously hard to assess, even when only nominal referents are investigated, as is commonly the case (see e.g. Prince 1981). For example, givenness may be assessed on the basis of both the textual and the situational context (Prince 1992). Furthermore, the simple given-new opposition does not work well for clauses, which are composite structures in which the information is hardly ever all given (although it may be all new). Thus, a slightly modified dichotomy was applied, inspired by Prince (1992) and Kreyer (2007).

- New $[\mathrm{N}]$ means "discourse-new", i.e. the clause conveys information not found in the preceding text.

- Anchored [A] indicates that at least part of the content of the adverbial clause is found in the preceding context. Generally, a clause was not considered anchored if only one of its constituents could be classified as given information.

Note that only the text itself was used as a basis for determining information status; Prince's category of 'situationally given' (Prince 1992) was not applied, as such givenness will vary across readers. There was no formal restriction on how far back in the context one should look for given information, but in practice, given the window size of the context in the software used, the span was approximately ten sentences (or s-units).

The typical pattern can be expected to be as in example (12), where the adverbial clause in sentence (i) is anchored (marked as [A]) in the description of the farm given in the previous context. The matrix clause is predominantly discourse-new (marked as $[\mathrm{N}]$ ), 
although 'he' refers anaphorically to 'Prince Charles'. Note that the initial anchored clause also gives a framework of interpretation for the rest of the passage, by specifying the fundamental premise for the ensuing events. In sentence (ii) the matrix contains references to both the farm and the sale implied in sentence (i). The adverbial clauses are discourse-new. (i.e. while it can be inferred that a farm that has become available is for sale, it cannot be inferred that this will happen 'without going on the market'. Sentence (iii) is much like (ii) in that the matrix contains references to the preceding context while the sentence-final adverbial clause has discourse-new information.

(12) [Context: description of a farm next to a property owned by Prince Charles] (i) Yesterday after the 80-acre farm became 'unexpectedly available' [A], moves were being made to ensure he gets the chance to buy it without fear of outside competition. (ii) It is being put up for sale without going on the market and without being advertised [N]. (iii) Those involved in the deal are keeping details secret to avoid putting the sale in jeopardy [N]. (ICE-GB: W2C)

Example (13), on the other hand, is text-initial, so both the matrix and the adverbial clause contain new information. However, it is the information in the adverbial clause that is developed in the immediately following context, which makes end position a natural choice.

(13) HEAD TEACHERS are planning to challenge a key part of the government's education reforms by opting out of the national curriculum which lays down what children should learn. (ICE-GB: W2C)

On the basis of previous findings regarding adverbial placement in English (Hasselgård 2010), it is expected that the news texts will pay more attention to information structure, while the fiction texts will pay more attention to cohesion. Fig. 4 shows the distribution of anchored and new adverbial clauses in initial position. ${ }^{5}$ Since it is impossible to assess information value in a fully objective manner even when only the textual context is considered, and I did not have the opportunity to have the material assessed by a second analyst, the numbers may not be entirely accurate. However, they show such a clear trend that I believe they are reliable enough for the present purposes.

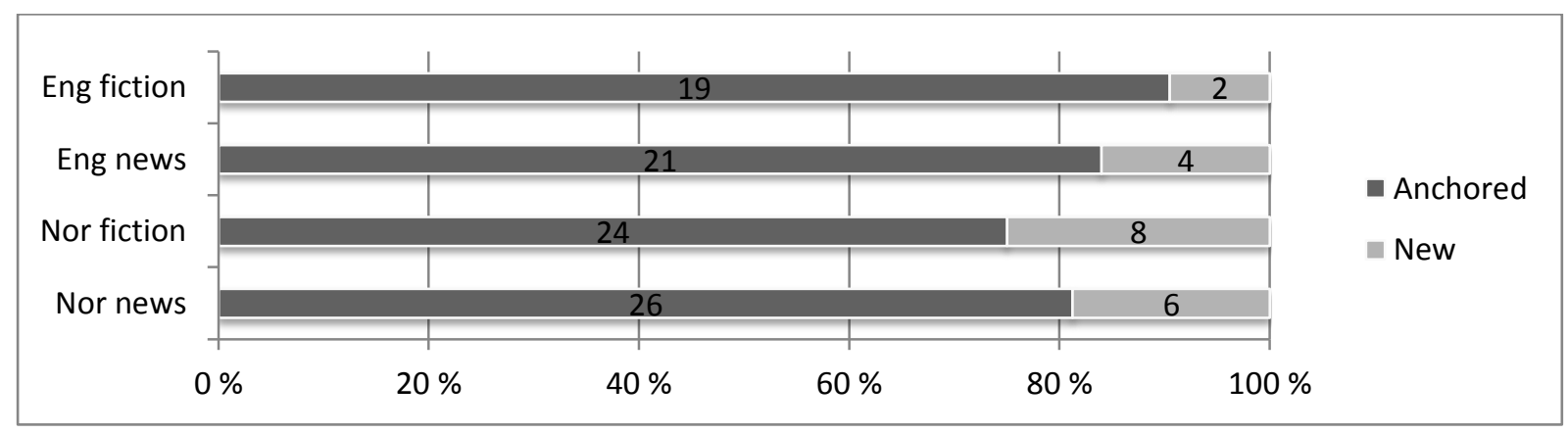

Fig. 4 Anchored and new information in initial position

\footnotetext{
${ }^{5}$ Note that the study of information structure is restricted to time and contingency clauses, which are the only ones to vary between initial and end position.
} 
The numbers underlying Fig. 4 are small, and percentages may enlarge the differences between languages and registers. However, the general trend is clear, and the patterns in Fig. 4 support the main hypothesis about information structure: initial adverbial clauses are anchored in the majority of the cases, as illustrated by sentence (i) in example (12). Anchored initial clauses mainly co-occur with either discourse-new or anchored matrixes. Discoursenew initial adverbials, in contrast, typically co-occur with discourse-new matrixes, e.g. in text-initial sentences. There are more new initial clauses in Norwegian than in English, especially in fiction.

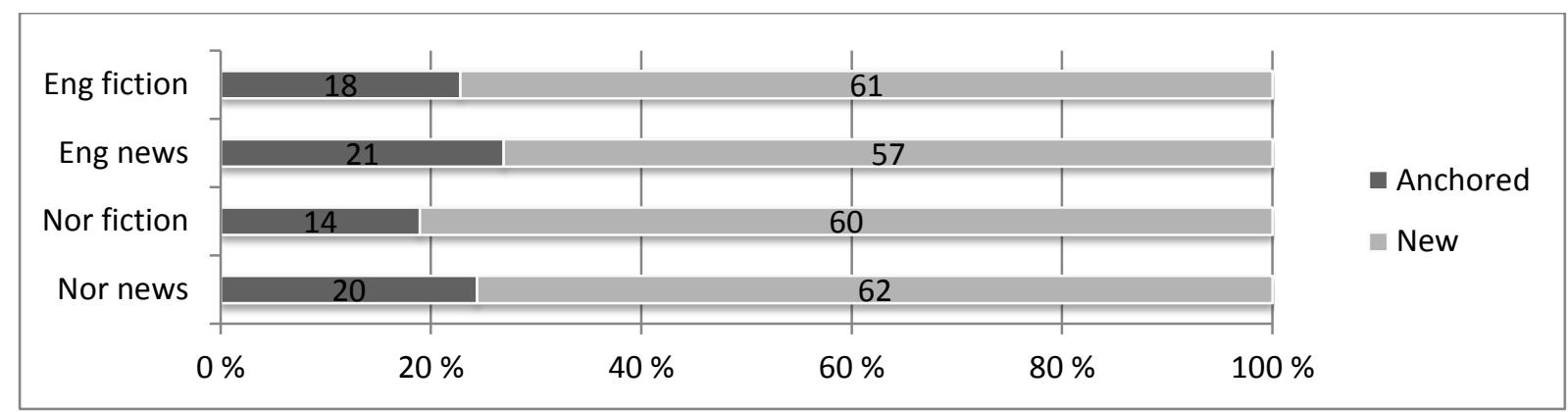

Fig. 5 Anchored and new information in end position

Fig. 5 shows the distribution of anchored and new adverbial clauses in end position, and gives an almost reverse picture of the patterns in initial position: the information is discourse-new in $75-80 \%$ of the cases. Anchored adverbial clauses in end position co-occur with anchored and new matrixes about equally often. There is little difference between the languages. However, the registers differ: the proportion of anchored adverbial clauses in end position is greater in news in both languages. Information load thus seems to be a good predictor of adverbial clause placement. ${ }^{6}$ However, the apparently neat patterns involve a potential chicken-and egg problem: since syntactic subordination may signal downgrading of information, the fact that a proposition contains anchored information may cause the writer to encode it as a subordinate clause and place it in initial position.

In any case the investigation of information structure has shown that adverbial clauses introducing new information are indeed more frequent in end position in both languages, while those carrying information anchored in the preceding context are more frequently initial. Similarly, clauses with information that is developed in the following context are more likely to be final. However, the picture is not consistent: anchored information can occur in end position - and there are more cases of this than of new information in initial position.

\section{$7 \quad$ Adverbial Clause Placement and Iconic Order}

One of Enkvist's (1981) text strategies is experiential iconicism, or 'natural order': this principle (also advanced by other linguists, see e.g. Fossestøl (1980) Ramsay (1987) and

\footnotetext{
${ }^{6}$ In fact, Fisher's exact test shows it to be highly significant for the selection of position, at $\mathrm{p}<0.0001$ for all parts of the material.
} 
Hwang (1994)), predicts that events will be presented in the order in which they occur. According to Diessel (2005: 463), "there is a tendency to arrange clauses in an iconic order such that linear clause order reflects the temporal ordering of the events they describe". This is illustrated in (14), from Norwegian fiction (its English translation, from the ENPC, closely follows the original): the arrival at the steps is prior to the removal of hat and gloves.

(14) Da han kom fram til trappen, stanset han, tok av seg pelsluen og hanskene. (LSC2)

When he got to the steps he stopped and took off his fur hat and gloves. (LSC2T)

(15) Lente jeg meg langt nok ut og så den andre veien, kunne jeg få et glimt av pissoaret nedenfor Fagerborg kirke. (LSC2)

If I leaned out far enough and looked the other way, I could get a glimpse of the urinals down by Fagerborg Church. (LSC2T)

The principle of temporal iconicism may apply to clauses other than temporal ones too, as illustrated by (15): the leaning out is not only a condition for seeing the urinals, it also needs to be prior in time. Kortmann (1991: 137) discovered "marked tendencies for adjuncts/absolutes expressing 'time before' or condition to precede their matrix clause, and for those receiving a 'time after', result, purpose, contrast, addition/accompanying circumstance or exemplification/specification interpretation to occur in final position". In similar fashion one might expect conditions to occur before consequences (Ford 1993, Hasselgård 2014b), as in (15), and cause to be mentioned before effect (although Altenberg (1987) and Diessel (2008) have shown that this is not necessarily the case).

The analysis of iconicism was manual, based on close reading of each adverbial clause in relation to its matrix clause. As in the study of information structure, only time and contingency clauses were considered. Fig. 6 shows the proportion of clauses that reflect what will henceforth be referred to as 'iconic order'. This order is slightly more frequent in English than in Norwegian. As regards the register comparison, the iconic order is slightly more frequent in fiction than in news in both languages, but not significantly so. ${ }^{7}$

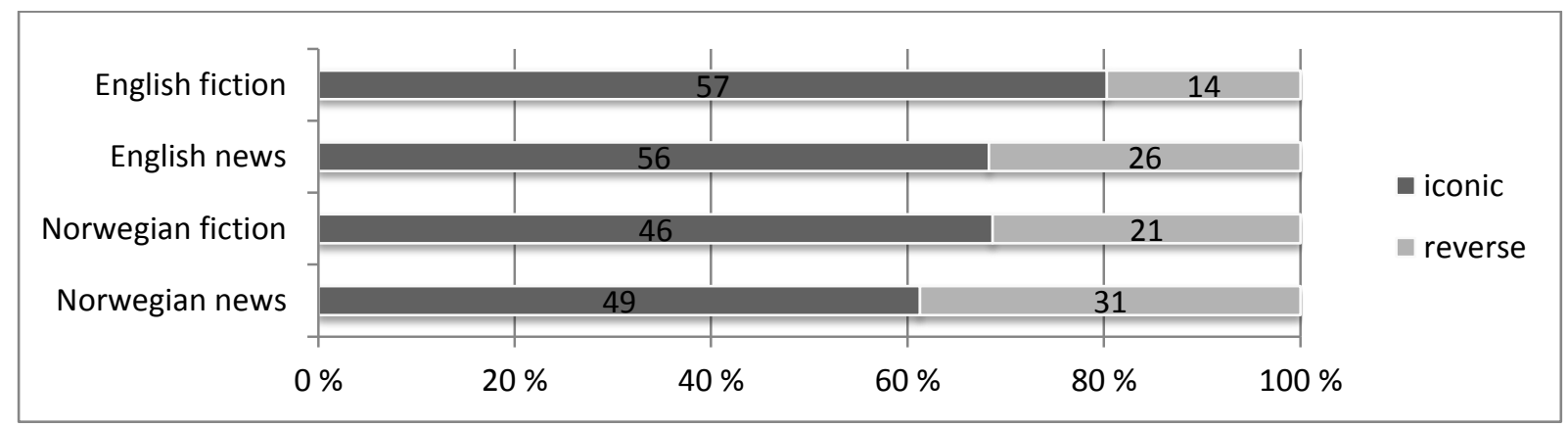

Fig. 6 The iconic principle in the order of adverbial and matrix clauses

\footnotetext{
${ }^{7}$ Significance according to Fisher's exact test: English news vs. English fiction: $\mathrm{p}=0.1006$; Norwegian news vs. Norwegian fiction: $\mathrm{p}=0.3894$; Norwegian fiction vs. English fiction: $\mathrm{p}=0.1235$; Norwegian news vs. English news: $\mathrm{p}=0.4114$.
} 
Based on previous findings, e.g. Diessel (2008), it appears that a more fine-grained semantic division of adverbial clauses is needed for a study of iconic order. In particular, conditional and causal clauses should not be lumped together, as they have very different positional patterns (Diessel 2008, Hasselgård 2014b). It is important to note that iconic order works differently with different types of adverbial clauses. For time clauses, iconic order implies that the order of clauses mirrors the temporal succession of events. Thus a temporal clause will precede its matrix if it is about an event prior to the matrix event (and vice versa). For conditional clauses, iconic order means that the protasis precedes the apodosis, i.e. the condition is mentioned first. For causal clauses iconic order implies that cause is mentioned before effect. This might pull causal (because) clauses to initial position and defer purpose and result clauses to end position.

Table 5 presents the placement of subcategories of contingency and time clauses. Time clauses have been subdivided according to their temporal relationship with the matrix clause; i.e. whether they refer to an event occurring before that of the matrix clause (MC) after it, or simultaneously with it (cf. also Diessel 2008: 473). The shaded cells mark iconic order; bold type marks the most frequent position.

Table 5 Adverbial clause meanings and iconic order (marked by shaded cells). Raw frequencies

\begin{tabular}{|l|l|l|l|l|l|l|l|l|}
\hline & \multicolumn{2}{|l|}{ English fiction } & \multicolumn{2}{l|}{ English news } & \multicolumn{2}{l|}{ Norwegian fiction } & \multicolumn{2}{l|}{ Norwegian news } \\
\hline & Initial & End & Initial & End & Initial & End & Initial & End \\
\hline Condition & $\mathbf{9}$ & 6 & $\mathbf{1 3}$ & 8 & $\mathbf{7}$ & 2 & $\mathbf{1 5}$ & 12 \\
\hline Cause & 0 & $\mathbf{2}$ & 0 & $\mathbf{7}$ & 2 & $\mathbf{4}$ & 1 & $\mathbf{1 4}$ \\
\hline Purpose & 0 & $\mathbf{3 1}$ & 0 & $\mathbf{2 9}$ & 0 & $\mathbf{1 7}$ & 2 & $\mathbf{2 2}$ \\
\hline Result & 0 & 0 & 0 & $\mathbf{1}$ & 0 & 0 & 0 & $\mathbf{1}$ \\
\hline Concession & 1 & $\mathbf{2}$ & $\mathbf{3}$ & 1 & 1 & 1 & $\mathbf{3}$ & 1 \\
\hline Time before MC & 2 & 2 & 5 & $\mathbf{1 0}$ & 8 & $\mathbf{1 3}$ & 5 & $\mathbf{1 5}$ \\
\hline Time after MC & 2 & $\mathbf{1 4}$ & 0 & $\mathbf{5}$ & 2 & $\mathbf{1 1}$ & 1 & $\mathbf{2}$ \\
\hline Simultaneous & 7 & $\mathbf{2 2}$ & 3 & $\mathbf{1 7}$ & 12 & $\mathbf{2 6}$ & 3 & $\mathbf{1 4}$ \\
\hline
\end{tabular}

As Table 5 shows, most time clauses occur in end position in both languages and in both registers, whether they refer to an event that is prior to, simultaneous with, or posterior to that of the matrix clause. There is thus no consistent reflection of iconic order. However, a time adjunct that denotes an event prior to the one in the matrix clause, as in (16), seems more likely to be initial than one that denotes an event posterior to the matrix event. However, end position is more common even for adverbial clauses denoting prior events; example (17) illustrates this. ${ }^{8}$ For temporal clauses denoting an event that follows the one in the matrix clause, initial position is unlikely, albeit not impossible.

(16) Once that is achieved, he still faces the choice of whether to call a General Election in June ... (ICE-GB:W2C)

\footnotetext{
${ }^{8}$ Diessel (2008: 474) reports a slight majority of initial placement of "prior" temporal clauses, and of the temporal clauses placed in initial position, a clear majority reflect iconic order. However, the adverbial clauses in end position do not reflect iconicity to the same extent (ibid.: 475).
} 
(17) Men gamle kelner Olesen dukket opp da Helen kom inn i kafeen. (OEL1) But the old waiter Olesen appeared when Helen came into the cafe. (OEL1T)

Conditional clauses are the only ones to consistently precede the matrix more often than they follow it although end position is only slightly less common. The same tendencies can be observed in both languages and both registers. Many of the clause-final conditionals occur in dependent matrix clauses (as in (19)), especially in Norwegian.

(18) Og hvis du ser dem i фyet, blir du gal. (TB1)

And if you look them in the eye you go mad. (TB1T)

(19) Myndighetene har en plan for å motta innvandrere om de kommer, sa innenriksminister Robert Maroni på en pressekonferanse. (News: DAV2) Lit: "The authorities have a plan for receiving the immigrants if they come, said the minister for domestic affairs RM at a press conference."

Purpose and result clauses occur almost consistently in end position across the material, in agreement with iconic order, as they convey a possible outcome of the matrix clause situation. Note, however, that purpose clauses tend to be non-finite in both languages, which is another strong reason why they should favour end position, cf. sect. 5.2. Examples are given in (20) and (21).

(20) Purpose: Fredsprisvinneren Muhammad Yunus går til retten for å påklage avskjedigelsen fra Grameen Bank. (News: VL2)

Lit: "Peace prize winner M. Yunus goes to court to appeal against his dismissal from Grameen Bank."

(21) Result: People would get full counselling before starting the process of buying so that they were aware of the commitments of home ownership. (ICE-GB: W2C)

Causal clauses occur predominantly in end position, thus violating iconic order. However, this was expected on the basis of Altenberg's (1987) and Diessel's (2008) findings as well as the predictions of Fossestøl (1980) and Faarlund et al. (1997). The typical order is thus as shown in (22).

(22) Og det var blitt for sent fordi pengene egentlig aldri hadde interessert ham. (OEL1)

And it had been too late because the money had never really interested him. (OEL1T)

\section{Summary of Findings and Concluding Remarks}


The present investigation has reaffirmed the fact that register is a factor that cannot be ignored in studies of grammar and discourse organization. While this is becoming an established truth in usage-based studies of English, it has as yet not been visible in studies of Norwegian. Furthermore, the frequency information about Norwegian adverbial clause placement has given a more accurate and nuanced picture of language use in this area than what has emerged from previous descriptions.

The cross-linguistic comparison has shown that English and Norwegian are alike in placing adverbial clauses predominantly in initial and end position while medial position is rare. End position is the more common choice in both languages and in both registers investigated. The first hypothesis presented in sect. 4 was that Norwegian would use initial position more often than English. The material showed no consistent pattern: there was a greater proportion of adverbial clauses in initial position in Norwegian fiction than in English fiction, but the other way round in the news register. Thus, the register comparison also turned out to have conflicting results: news has a greater proportion than fiction of its adverbial clauses in initial position only in English. The hypothesis of news making more extensive use than fiction of initial position for adverbial clauses was thus true only of contingency clauses, not of temporal ones. No other semantic types were frequent enough to show reliable patterns of variation between initial and end position.

It was clear that the syntactic type of adverbial clause influences its position in both languages: non-finite clauses occur less freely in initial position. Prepositional finites (occurring in Norwegian only) follow the same positional tendencies as their non-finite counterparts. Different semantic categories also have their own positional preferences in both languages. The preferences are rather similar across languages and registers. Contingency clauses are slightly more frequent in initial position in news, and time clauses in fiction.

The study of information structure and iconic order concerned only time and contingency clauses, as these were the only ones to be frequent enough in both initial and end position to study positional variation. The results show that adverbial clauses containing anchored information are more likely to be sentence-initial, and those with new information are more likely to be sentence-final. Initial clauses with new information are likely to cooccur with new matrix clauses.

The principle of iconic order would predict that causes and conditions are mentioned before consequences and that temporal clauses are placed such that the order of adverbial and matrix clause reflects the temporal succession of events. There was, however, no clear evidence in the material that iconicism was vital to adverbial clause placement, except possibly with regard to condition and purpose clauses, which showed definite preferences for initial and end position, respectively. It is, however, likely that the positional preferences of semantic categories are more important than iconic order, since other semantic categories do not seem much affected by iconicism.

The best predictors of adverbial clause placement thus seem to be finiteness and semantic category. Among finite time and contingency clauses, information value is also a good predictor of position. There were surprisingly few cross-linguistic differences apart from frequency: Norwegian and English adverbial clauses seem to be placed according to the same semantic and discourse-pragmatic principles. 
The register comparison revealed the following tendencies: the frequencies of adverbial clauses in both positions differed between registers but in opposite directions in English and Norwegian. Iconic order was slightly more frequent in fiction in both languages. Anchored clauses were most common in initial position across the material, but initial discourse-new clauses were more frequent in fiction than in news in Norwegian, but more frequent in news than in fiction in English. Discourse-new clauses were most common in end position in all the subcorpora but surprisingly there was a slightly higher percentage of final anchored clauses in news (in both languages).

The relatively inconclusive results, mainly due to the small size of the material, call for further research into the positional variation of adverbial clauses across languages and registers. Any further analysis of information structure and iconic order would benefit from a larger sample as well as additional registers and a broader text distribution.

\section{References}

Altenberg, Bengt. 1987. Causal ordering strategies in English conversation. In Grammar in the construction of texts, ed. J. Monaghan, 50-64. London: Francis Pinter.

Biber, Douglas, Stig Johansson, Geoffrey Leech, Susan Conrad \& Edward Finegan. 1999. Longman grammar of spoken and written English. London: Longman.

Diessel, Holger. 2001. The ordering distribution of main and adverbial clauses: A typological study. Language, 77:2, 433-55.

Diessel, Holger. 2005. Competing motivations for the ordering of main and adverbial clauses. Linguistics 43(3), 449-470.

Diessel, Holger. 2008. Iconicity of sequence. A corpus-based analysis of the positioning of temporal adverbial clauses in English. Cognitive Linguistics 19, 457-82.

Enkvist, Nils Erik. 1981. Experiential iconicism in text strategy. Text, 1 (1), 97-111.

Faarlund, Jan Terje, Svein Lie, Kjell Ivar Vannebo (1997). Norsk referansegrammatikk. Oslo: Universitetsforlaget.

Ford, Celia. E. \& Sandra A. Thompson. 1986. Conditionals in discourse: a text-based study from English. In E.C. Traugott, A. ter Meulen, J.S. Reilly, C.A. Ferguson (eds.) On conditionals (pp. 353-372). Cambridge University Press.

Fossestøl, Bernt. 1980. Tekst og tekststruktur: veier og mål i tekstlingvistikken. Oslo: Universitetsforlaget.

Hasselgård, Hilde. 2010. Adjunct adverbials in English. Cambridge: Cambridge University Press.

Hasselgård, Hilde. 2014a. Discourse-structuring functions of initial adverbials in English and Norwegian news and fiction. In Genre- and register-related discourse features in contrast, eds. M.-A. Lefer \& S. Vogeleer. Special issue of Languages in Contrast 14(1), 73-92.

Hasselgård, Hilde. 2014b. Conditional clauses in English and Norwegian. In Affaire(s) de grammaire, eds. H.P. Helland \& C.M. Salvesen, 183-200. Oslo: Novus.

Hetterle, Katja. 2015. Adverbial clauses in cross-linguistic perspective. Berlin/Boston: de Gruyter Mouton. 
Hwang, Shin Ja Joo. 1994. Relative clauses, adverbial clauses, and information flow in discourse. Language Research, Volume 30(4), 673-705.

Kortmann, Bernd. 1991. Free adjuncts and absolutes in English: Problems of control and interpretation. London/New York: Routledge.

Kreyer, Rolf. 2007. Inversion in modern written English: syntactic complexity, information status and the creative writer. In Corpus linguistics 25 years on, ed. R. Facchinetti, 187-204. Amsterdam: Rodopi.

Matthiessen, Christian \& Sandra Thompson. 1988. The structure of discourse and 'Subordination'. In Clause combining in discourse and grammar, eds. J. Haiman \& S. Thompson, 275-329. Amsterdam/Philadelphia: Benjamins.

Meier, Einar. 2001. "Since you mention it": A contrastive study of causal subordination in English and Norwegian. MA thesis, University of Oslo. www.hf.uio.no/ilos/forskning/prosjekter/sprik/pdf/em/HovedoppgEinarMeier22.pdf

Prince, Ellen F. 1992. The ZPG letter: Subjects, definiteness, and information-status. In Discourse description: Diverse linguistic analyses of a fund-raising text, eds. W.C. Mann \& S.A. Thompson, 295-326. Amsterdam: Benjamins.

Ramsay, Violeta. 1987. The functional distribution of preposed and postposed IF and WHEN clauses in written narrative. In Coherence and grounding in discourse, ed. R. Tomlin, 383-408. Amsterdam: Benjamins.

Scott, Mike. 2014. WordSmith Tools 6. Stroud: Lexical Analysis Software.

Thompson, Sandra A., Robert E. Longacre, Shin Ja Joo Hwang. 2007. Adverbial clauses. In Language typology and syntactic description. Volume II: Complex constructions, ed. T. Shopen, 237-300. Cambridge: Cambridge University Press.

Wiechmann, Daniel \& Elma Kerz. 2013. The positioning of concessive adverbial clauses in English: assessing the importance of discourse-pragmatic and processing-based constraints English Language and Linguistics, 17 :1, 1-23. DOI: 10.1017/S1360674312000305.

\section{Corpus Material}

English-Norwegian Parallel Corpus (ENPC), excerpts from Toril Brekke, Jacarandablomsten / The Jacaranda Flower (TB1), Lars Saabye Christensen, Jokeren / The Joker (LSC2) and Øystein Lønn, Tom Rebers siste retrett / Tom Reber's Last Retreat (OEL1), see www.hf.uio.no/ilos/english/services/omc/enpc/

International Corpus of English, British component (ICE-GB): www.ucl.ac.uk/englishusage/projects/ice-gb/, texts W2C-001, 002, 015, 018, 020 (press reportage) and W2F001, 002, 003, 007, 012 (fiction).

Norwegian newspapers - news articles from the online versions of some Norwegian national daily newspapers 3 March 2011 (Dagsavisen, Aftenposten, VG, Vårt Land, Klassekampen, Nationen, Dagens Naringsliv) 